\title{
Social Capital of Jenukuruba Tribal Women
}

\author{
V. Pavithra*, K. P. Raghuprasad, Tanweer Ahmed and G. Chandrashekar \\ University of Agricultural Sciences, Bengaluru, India \\ *Corresponding author
}

\section{Keywords}

Tribe, Jenukuruba, Social capital women

\section{Article Info}

Accepted:

24 August 2020

Available Online:

10 September 2020

\begin{abstract}
A B S T R A C T
The study was carried in Heggadadevanakote taluk of Mysuru district during 2019 to assess the social capital of Jenukuruba tribal women. Ex post facto research design was employed for the study. With respect to overall social capital status of Jenukuruba tribal women, It was found that there was medium level social capital (46.67\%) followed by low $(33.33 \%)$ and high level $(20.00 \%)$. Among different dimensions of social capital, trust and solidarity got the highest mean score (17.13) followed by groups and network (16.16), empowerment and action (12.13) collective action and co-operation (8.63), information and communication (4.67) and social cohesion and inclusion (2.83). Based on the results, it can be concluded that there is a need to build social capital by addressing all the dimensions among tribal women to make them more empowered socially, economically and culturally particularly social cohesion and information communication has to be promoted among the Jenukuruba tribal women.
\end{abstract}

\section{Introduction}

The name 'Jenukuruba' is derived from their occupation of roaming in the forests in search of honey, edible tubers, fruits etc. they inhibit 2000 sq. kms in the conclave of Karnataka, Tamil Nadu and Kerala sates. They have negroid features like short stature, curly hair and generally dark complexion etc. They are also referred to by the names 'Then Kurumba' or 'KattuNaikar.' Most of them work as daily laborers for landlords in plantations in the region. Being a close-knit community, they rarely mingle with other neighboring tribal communities. The consequences of doing so are severe. If any Jenukuruba becomes friendly with an outsider, he will be expelled from his community.
Jenukurubas of Mysore district use ethnomedicinal plants. They can identify different varieties of trees by its use, medicinal herbs, known behavioral patterns of animals, developed their own technique of selfdefense, their method of acing forest fire is even adopted by the forest department.

Social capital is an important dimension for development which is shrinking in developing countries in recent years. Sound social capital would play a decisive role in creating sustainable livelihood among rural masses. Social capital building approaches are increasingly used in poverty alleviation \& empowerment programs. Further, the social capital is linked to people, their lives and their surroundings. However, social capital can 
also be defined as the resources available to one through the networks that they hold. Social capital is not just the sum of the institutions that underpin a society but it is the glue that holds them together".

Social capital not only helps to alleviate rural poverty but also helps in maintaining social and environmental balance. Even then the communities like tribes can come together only through sound social capital for their empowerment. Even then limited attempts have been done to study their social capital and built accordingly.

\section{Materials and Methods}

The present study was conducted in Heggadadevanakote taluk of Mysuru district in the year 2019. Further Antharasanthehobli was selected for the study, since this hobli comprised Jenukurubatribal community. From among the settlements Hosahallihadi, Hunasekuppehadi and Kempanahadi from Antharasanthehobli were selected, where maximum number of Jenukurubas population living together and sample of 10 from each hamlet were randomly selected and total constituting of 30 samples.

Data was collected personally through structured interview schedule. The collected data was analysed using appropriate statistical tools like mean, frequency, standard deviation etc.

The Ex-post-facto research design was employed for the study. Social capital of tribal women was measured by making use of the scale developed by Raghuprasad (2007) with slight modifications.

There are six dimensions to measure of social capital of tribal women viz, (i) Empowerment and action (ii) Group and network, (iii) Trust and solidarity (iv) Collective action and cooperation (v) Information and communication (vi) Social cohesion and inclusion.

\section{Results and Discussion}

\section{Socio-economic profile of Jenukuruba tribal women}

\section{Age}

It could be seen from the table 1 that half $(50.00 \%)$ of Jenukuruba tribal women respondents belong to middle age, while onethird $(33.33 \%)$ belonged to young age group and the rest 16.66 per cent were in old age group.

\section{Education}

Data tabulated in the table 1 depicts that 43.33 per cent of Jenukuruba tribal women had primary school education followed by 40.00 per cent were illiterates and 16.66 per cent higher primary education.

\section{Family type}

It is tangible from the table 1 that majority $(76.66 \%)$ of Jenukurubatribal women belonged to nuclear family and 23.33 per cent of them belonged to joint family.

\section{Marital status}

A glimpse through the table 1 revealed that 76.66 per cent of the Jenukurubatribal women were married, 13.33 per cent of them were unmarried and 10.00 per cent of them were widows.

\section{Land ownership}

A close perusal of table 1 shows that more than half $(53.33 \%)$ of the Jenukurubatribal women had no land in their name and 46.66per cent of them owned land. 


\section{Livestock possession}

From the table 1 it is evident that more than half $(56.66 \%)$ of the Jenukuruba tribal women had medium level of livestock possession followed by low $(23.33 \%)$ and high $(20.00$ $\%)$ level.

\section{Annual income}

A critical analysis of table 1 shows that 40.00 per cent of the Jenukuruba tribal women had 10,000-20,000 annual income followed by 36.66 per cent had less than 10,000 income and 23.33per cent of them had annual income ranging 20,000-40,000.

\section{Mass media exposure}

A bird's eye view of table 1 clearly indicates that 43.33 per cent of the Jenukuruba tribal women had medium level of mass media exposure, followed by high $(33.33 \%)$ level of mass media exposure. While 23.33 per cent of the respondents had low level of mass media exposure.

\section{Extension participation}

Findings of the table 1 indicated that 43.33 per cent of the respondents had low level of extension participation followed by one-third $(33.33 \%)$ of them had medium level and 23.33 per cent had high level of extension participation.

\section{Decision making ability}

The data relevant to decision making ability is presented in table 1 shows 40.00 per cent of the Jenukuruba tribal women had medium decision making ability followed by one third (33.33\%) of them had low decision making ability and 23.33 per cent had high level of decision making among Jenukuruba tribal women.

\section{Risk orientation}

A close perusal of table 1 shows the distribution of Jenukuruba tribal women respondents based on their risk orientation. It reveals that 30.00 per cent of the tribal women had low level of risk orientation followed by 26.66 per cent of them had medium level of risk orientation and 23.33 per cent of them had high level of risk orientation.

\section{Institutional participation}

From the findings tabulated in table 1 it can be found out that half $(50.00 \%)$ of the Jenukuruba tribal women had low level of institutional participation followed by 40.00 per cent had medium level of institutional participation and 10.00per cent of them had high level of institutional participation.

\section{Social exclusion}

A critical analysis of table 1 indicates the extent of social exclusion of Jenukuruba tribal women. It was found that 46.66 per cent of the respondents were fully excluded followed by 40.00 per cent of them were partially excluded and 13.33 per cent were not excluded.

Dimension wise social capital status of Jenukuruba tribal women

Table 2 indicates dimension wise social capital status of Jenukuruba tribal women. Under the dimension empowerment and action it was found that 43.33 per cent of respondents belong to medium category followed by high $(30.00 \%)$ level and low level $(26.67 \%)$. As far as groups and network is concerned it was found that 53.33 per cent of respondents belong to medium category followed by high (36.67\%) and low level $(10.00 \%)$. 
Table.1 Socio-economic profile of Jenukuruba tribal women $(\mathrm{n}=30)$

\begin{tabular}{|c|c|c|c|}
\hline \multirow[t]{2}{*}{ Characteristics } & \multirow[t]{2}{*}{ Category } & \multicolumn{2}{|c|}{ Jenu Kuruba } \\
\hline & & Number & Percentage \\
\hline \multirow[t]{3}{*}{ Age } & Young & 10 & 33.33 \\
\hline & Middle & 15 & 50.00 \\
\hline & Old & 05 & 16.66 \\
\hline \multirow[t]{3}{*}{ Education } & Illiterate & 12 & 40.00 \\
\hline & Primary Education & 13 & 43.33 \\
\hline & Higher primary & 05 & 16.66 \\
\hline \multirow[t]{2}{*}{ Family type } & Nuclear & 23 & 76.66 \\
\hline & Joint & 07 & 23.33 \\
\hline \multirow[t]{3}{*}{ Marital status } & Unmarried & 04 & 13.33 \\
\hline & Married & 23 & 76.66 \\
\hline & Widow & 3 & 10.00 \\
\hline \multirow[t]{2}{*}{ Land ownership } & Un-owned & 16 & 53.33 \\
\hline & Owned & 14 & 46.66 \\
\hline \multirow{3}{*}{$\begin{array}{l}\text { Live stock possession } \\
\text { Mean=1.24 } \\
\text { SD=0.48 }\end{array}$} & Low $(<0.99)$ & 07 & 23.33 \\
\hline & Medium (0.99-1.48) & 17 & 56.66 \\
\hline & High $(>1.48)$ & 06 & 20.00 \\
\hline \multirow[t]{3}{*}{ Annual income } & Less than 10,000 & 11 & 36.66 \\
\hline & $10,000-20,000$ & 12 & 40.00 \\
\hline & $20,000-40,000$ & 07 & 23.33 \\
\hline \multirow{3}{*}{$\begin{array}{l}\text { Mass media exposure } \\
\text { Mean=2.2 } \\
\text { SD=0.76 }\end{array}$} & Low $(<1.81)$ & 07 & 23.33 \\
\hline & Medium (1.81-2.58) & 13 & 43.33 \\
\hline & $\operatorname{High}(>2.58)$ & 10 & 33.33 \\
\hline \multirow{3}{*}{$\begin{array}{l}\text { Extension } \\
\text { participation } \\
\text { Mean=2.83 } \\
\text { SD=0.76 }\end{array}$} & Low $(<2.32)$ & 13 & 43.33 \\
\hline & Medium (2.32-3.34) & 10 & 33.33 \\
\hline & High $(>3.34)$ & 07 & 23.33 \\
\hline \multirow{3}{*}{$\begin{array}{l}\text { Decision making } \\
\text { ability } \\
\text { Mean }=2.53 \\
\text { SD=1.07 }\end{array}$} & Low $(<1.99)$ & 10 & 33.33 \\
\hline & Medium (1.99-3.07) & 14 & 46.66 \\
\hline & High $(>3.07)$ & 06 & 20.00 \\
\hline \multirow{3}{*}{$\begin{array}{l}\text { Risk orientation } \\
\text { Mean=1.97 } \\
\text { SD=1.15 }\end{array}$} & Low $(<1.38)$ & 12 & 30.00 \\
\hline & Medium (1.38-2.54) & 11 & 26.66 \\
\hline & High $(>2.54)$ & 07 & 23.33 \\
\hline \multirow{3}{*}{$\begin{array}{l}\text { Institutional } \\
\text { participation }\end{array}$} & Low & 15 & 50.00 \\
\hline & Medium & 12 & 40.00 \\
\hline & High & 03 & 10.00 \\
\hline \multirow[t]{3}{*}{ Social exclusion } & Fully excluded & 14 & 46.66 \\
\hline & Partially excluded & 12 & 40.00 \\
\hline & Not excluded & 04 & 13.33 \\
\hline
\end{tabular}


Table.2 Dimension wise social capital status among Jenukuruba tribal women $(n=30)$

\begin{tabular}{|c|c|c|c|c|c|}
\hline \multirow{2}{*}{$\begin{array}{c}\text { Dimensions of Social } \\
\text { Capital }\end{array}$} & \multicolumn{3}{|c|}{ Jenukuruba } & \multirow[t]{2}{*}{ Mean } & \multirow[t]{2}{*}{ SD } \\
\hline & Category & No. & $\%$ & & \\
\hline \multirow{3}{*}{$\begin{array}{l}\text { Empowerment and } \\
\text { Action }\end{array}$} & Low $(<11.45)$ & 08 & 26.67 & \multirow[t]{3}{*}{12.13} & \multirow[t]{3}{*}{1.36} \\
\hline & Medium (11.45-12.81) & 13 & 43.33 & & \\
\hline & $\operatorname{High}(>12.81)$ & 09 & 30.00 & & \\
\hline \multirow[t]{3}{*}{ Groups and Network } & Low $(<15.48)$ & 03 & 10.00 & \multirow[t]{3}{*}{16.16} & \multirow[t]{3}{*}{1.37} \\
\hline & Medium (15.48-16.85) & 16 & 53.33 & & \\
\hline & High $(>16.85)$ & 11 & 36.67 & & \\
\hline \multirow[t]{3}{*}{ Trust and Solidarity } & Low $(<15.55)$ & 06 & 20.00 & \multirow[t]{3}{*}{16.47} & \multirow[t]{3}{*}{1.81} \\
\hline & Medium (15.55-17.37) & 15 & 50.00 & & \\
\hline & $\operatorname{High}(>17.37)$ & 09 & 30.00 & & \\
\hline \multirow{3}{*}{$\begin{array}{l}\text { Collective Action and } \\
\text { Co-operation }\end{array}$} & Low $(<8.01)$ & 13 & 43.33 & \multirow[t]{3}{*}{8.63} & \multirow[t]{3}{*}{1.25} \\
\hline & Medium(8.01-9.25) & 09 & 30.00 & & \\
\hline & High $(>9.25)$ & 08 & 26.67 & & \\
\hline \multirow{3}{*}{$\begin{array}{l}\text { Information and } \\
\text { Communication }\end{array}$} & Low $(<4.36)$ & 12 & 40.00 & \multirow[t]{3}{*}{4.67} & \multirow[t]{3}{*}{0.60} \\
\hline & Medium (4.36-4.96) & 16 & 53.33 & & \\
\hline & High $(>4.96)$ & 02 & 06.67 & & \\
\hline \multirow{3}{*}{$\begin{array}{l}\text { Social Cohesion and } \\
\text { Inclusion }\end{array}$} & Low $(<2.46)$ & 05 & 16.67 & \multirow[t]{3}{*}{2.83} & \multirow[t]{3}{*}{0.74} \\
\hline & Medium (2.46-3.20) & 13 & 43.33 & & \\
\hline & $\operatorname{High}(>3.20)$ & 12 & 40.00 & & \\
\hline
\end{tabular}

Table.3 Overall social capital among Jenukuruba tribal women $(n=30)$

\begin{tabular}{|l|c|c|c|c|}
\hline \multirow{2}{*}{ Category } & \multicolumn{2}{|c|}{ JenuKuruba } & \multirow{2}{*}{ Mean } & SD \\
\cline { 2 - 3 } & No. & \% & & \\
\hline Low & 10 & 33.33 & 58.06 & 2.91 \\
\hline Medium & 14 & 46.67 & & \\
\hline High & 06 & 20.00 & & \\
\hline
\end{tabular}

With regard to trust and solidarity it was found that half of them were having medium level $(50.00 \%)$ followed by high level $(30.00 \%)$ and low level $(20.00 \%)$. Further it was found that 43.33 per cent of respondents belong to low category of collective action and co-operation followed by medium level $(30.00 \%)$ and high level (26.67\%). With respect to information and communication dimension, it shows that more than half $(53.33 \%)$ of them belong to medium category followed by low (40.00\%) and high (6.67\%). With respect to social cohesion and inclusion, it was found that 43.33 per cent belong to medium category followed by high level $(40.00 \%)$ and low level (16.67\%).

Majority of them belonging to medium level of empowerment and action. It is due to the reason that most of these tribes reasonably good in owning their land, medium level of livestock possession, medium level of mass media exposure might have contributed for these kinds of results. Further because of interventions of government programmes and activities of local NGOs they have moderately empowered. 
Since all these tribes are living together in their identified settlements they forcibly believe in groups and depend on each other. As a result majority of them expressed medium category with regard to groups and network.

Most of the Jenukuruba had medium trust and solidarity high number of nuclear families, low extension participation, low institutional participation were contributed for less trust and solidarity. Further being geographical and social isolation community normally they don't simply believe external agencies immediately. The results were supported by findings of Raghuprasad (2007).

With regard to collective action and cooperation it is quite evident to note that majority of them were having low collective action because they do not mingle freely with either the people of their community or outsiders, further more number of their nuclear families and medium level of institutional participation, hinders their collective activities. The results were in accordance with by findings of Raghuprasad (2007).

Information and Communication shows medium level because, of their medium level of mass media exposure and institutional participation. Further because of the initiatives and the benefits of the government programmes they were quite aware and expressed medium level of information and communication. The results were in line with findings of Raghuprasad (2007).

Further, the dimension like social cohesion and inclusion also shows medium level because of the fact that Jenukurubas were primitively possessing unique tradition and culture, having common occupation of collecting forest products might have responsible for greater social cohesion and inclusion. The results were supported by findings of Raghuprasad (2007).

\section{Overall social capital status among Jenukuruba tribal women}

The data recorded in table 3 depicts the overall social capital status of Jenukuruba tribal women. It indicates that there was medium level social capital (46.67 \%) followed by low $(33.33 \%)$ and high level $(20.00 \%)$.

The result of overall social capital status among different tribes indicated that majority of them expressed medium level of empowerment and action because of medium level of livestock possession and little education they possessed. Further, influence of other dimensions like groups and network, which was observed medium level since they are living together in isolated settlements having their own network due to of common language and culture. As far as trust and solidarity is concerned it is quite interesting to note that medium level trust and solidarity among them since they are less in number, more excluded from social system inevitably developed trust and solidarity for their survival. Collective action and cooperation it was at low level because they are not coming together for societal causes may be due to their more number of nuclear families, low income and less interest in community activities and so on. With regard to Information and Communication it was expressed medium due to moderate exposure to television media which is common in their households which provides wide range of information related to developmental initiatives besides there entertainment.

Finally, it was predominantly conclude that they have expressed high social cohesion and inclusion because of their Unique Identity culture, norms, taboos, common language, 
more or less equal socioeconomic status which bind their relationships and make them to be intact in their social system. The results were similar with the findings of Sajeev (2006).

In conclusion the Social capital is an important aspect to bring people together for development and inclusive growth specially among tribal women. There was low level of social capital among Jenukuruba tribal women and it is because of the isolation and less exposure to external world. Hence there is a need to build social capital addressing all the dimensions among tribal women to make them more empowered socially, economically and culturally particularly social cohesion and information communication has to be promoted among the Jenukuruba tribal women.

\section{References}

Adepoju, A. and Oni, O.A., 2011, Investigating endogenecity effects of social capital on household welfare in Nigeria: a control function approach. $J$. Int. Agri. 51(1): 73-96.

Adler Paul, S. and Kwon, S., 2002, Social capital: Prospects for a new concept. Acad. Manag. Rev. 27(1): 17-40.

Aswathy Chandrakumar., 2016, A study on social exclusion of Adiya tribal community of Wayanad district, Kerala. M. Sc. (Ag.) Thesis (Unpub.). University of Agricultural Sciences, Bengaluru.

Gangadharappa, N.R., David G. Acker, Chengappa, P.G., Ganesamoorthi S.,
Sunil Kumar, Sajeev M.V., and Difel SHEN, 2007, Social capital and ability to change among Indian farmers. Paper presented at Conference on international ising with cultural leadership held on May 20 to 23, 2007 at Polson, Montana. Association for International Agricultural and Extension Education.

Gangadharappa, N. R., Sajeev, M. V., Ganesamoorthi, S., NAGESHA, G., Ibrahim, S., RanganathA, A. D. AND REDDY, M., 2005, Exploratory study on economic and marketing aspects of agroforestry and their implications in Dharwad and Belgaum districts, Karnataka. My Forest, 41(2): 107-119.

Raghuprasa D, K. P., 2007, Dynamics of social capital and impact of extension interventions on mushroom cultivation among resource poor SC / ST rural women. Ph.D thesis (Unpub.). University of Agricultural Sciences, Bengaluru.

Ramya, H.R., 2016, Livelihood analysis of tribal farmers in high altitude tribal zone of Karnataka state. M.Sc.(Ag.) Thesis. Acharya N. G. Ranga Agricultural University, Guntur.

Sajeev, M.V., 2006, Scientists' perception and farmers' readiness towards GM crops. Ph.D. Thesis (Unpub.). University of Agricultural Sciences, Bangalore.

Sanyal, P., 2009, From credit to collective action: The role of microfinance in promoting Women's social capital and normative influence. Am. Sociological Rev. 74: 529-550.

\section{How to cite this article:}

Pavithra, V., K. P. Raghuprasad, Tanweer Ahmed and Chandrashekar, G. 2020. Social Capital of Jenukuruba Tribal Women. Int.J.Curr.Microbiol.App.Sci. 9(09): 3327-3333. doi: https://doi.org/10.20546/ijcmas.2020.909.414 